\title{
Pengaruh minuman jus buah dalam kemasan terhadap erosi gigi sulung anterior rahang atas
}

\author{
Dhea Marsya Permadhi ${ }^{1 *}$, Lindasari Sembiring ${ }^{1}$, Ibnu Suryatmojo ${ }^{2}$ \\ ${ }^{1}$ Departemen Pedodonti, Fakultas Kedokteran Gigi, Universitas Kristen Maranatha, Indonesia \\ ${ }^{2}$ Departemen Konservasi Gigi, Fakultas Kedokteran Gigi, Universitas Padjadjaran, Indonesia \\ *Korespondensi: dheamarsya@gmail.com
}

\begin{abstract}
ABSTRAK
Pendahuluan: Erosi gigi merupakan penyakit kronis yang paling sering terjadi pada anak dalam masalah kesehatan gigi. Penyebab erosi gigi yang paling sering terjadi adalah akibat makanan dan minuman yang asam. Perhatian khusus ditujukan kepada jus buah yang mengandung asam sitrat. Jus buah dipandang sebagai sumber nutrisi, sehingga orang tua tidak membatasi konsumsi pada anak. Tujuan penelitian ini adalah untuk mengetahui apakah terdapat pengaruh minuman jus buah dalam kemasan terhadap erosi gigi sulung anterior rahang atas. Metode: Penelitian ini merupakan penelitian eksperimental labolatorium semu. Penelitian ini menggunakan gigi anterior sulung rahang atas yang dialiri dengan cairan fisiologis pada kelompok kontrol, dan dialiri larutan jus buah dalam kemasan secara bergantian dengan pengaliran cairan fisiologis pada kelompok perlakuan. Pengujian karakterisasi dilakukan dengan Scanning Electron Microscope (SEM) untuk melihat perubahan ketebalan enamel gigi sebelum dan sesudah perlakuan dan uji analisis menggunakan Mann Whitney U Test dengan bantuan program Mega Stat Excel. Hipotesis statistik diterima jika p value $<0,05$.Hasil: Uji SEM menunjukkan bahwa beda ketebalan enamel pada kelompok perlakuan yang dialiri dengan minuman jus buah dalam kemasan lebih besar dibandingkan dengan kelompok kontrol yang dialirkan dengan cairan fisiologis. Pada spesimen kelompok perlakuan tampak mengalami perubahan mikrostruktur permukaan enamel akibat erosi dan sebagian mengalami pembentukkan mikroporositas pada permukaan enamel. Simpulan: terdapat pengaruh jus buah dalam kemasan terhadap erosi gigi.
\end{abstract}

Kata Kunci: Erosi gigi, gigi anterior sulung atas rahang atas, pengaruh minuman jus buah

\section{The Effect of Fruit Juice Drink In Package to Erosion Teeth Eldest Anterior Upper Jaw}

\section{ABSTRACT}

Introduction: In dental health problems, tooth erosion is the most common chronic disease that happen to children. The common etiology of tooth erosion is acidic food and beverages. Special attention is addressed to fruit juices that contains citric acid. Fruit juice considered nutritious as parents don't limit their children's consumption of fruit juice. The purpose of this study is to determine the effect of fruit juice in packages to the erosion of primary anterior maxillary teeth. Methods: This study is a laboratory quasy experiment. This study was using primary anterior maxillary teeth that channelled with saline solution in control group, and channelled with fruit juice and replaced saline solution in the treatment group. Characterization test using Scanning Electron Microscope (SEM) to analyse the changes of the enamel thickness before and after the treatment and an analysing test using Mann Whitney U Test in SPSS programme. Statistic hypothesis is accepted if $p$ value $<0,05$. Results: The result of SEM test showed the difference of enamel thickness in treatment group is greater than the difference of enamel thickness in control group. Speciments in treatment group shows microstructural changes on the enamel surfaces due the erosion and formed a microporosity on the enamel surface. Conclusion: there are effects of fruit juice in packages to the erosion of primary anterior maxillary teeth.

Keywords: Tooth erosion, maxillary deciduous anterior teeth, Fruit juice Scanning Electron Microscopy (SEM) 


\section{PENDAHULUAN}

Erosi gigi merupakan penyakit kronis yang paling sering terjadi pada anak pada masalah kesehatan gigi. Erosi gigi menyebabkan kehilangan struktur gigi, sehingga terjadi sensitivitas gigi, kesulitan makan, estetik yang buruk, oklusi yang berubah, dalam kasus yang parah dapat menyebabkan terpaparnya pulpa dan abses. ${ }^{1}$ Erosi gigi pada anak merupakan keadaan yang sering terjadi dan prevalensinya meningkat dalam beberapa dekade terakhir. Penelitian Wiegand et.al menunjukkan terdapat $32 \%$ prevalensi erosi gigi pada anak usia 2-7 tahun. Ayers et.al melaporkan terdapat $82 \%$ prevalensi erosi gigi pada anak usia 5-8 tahun. Menurut penelitian oleh Babu et.al, pada anak usia 4-15 tahun, $25.6 \%$ diantaranya mengalami erosi gigi. 1,2

Babu et.al menyatakan diantara 128 anak dengan erosi gigi, gigi sulung lebih banyak mengalami erosi sebesar $23,93 \%$, sedangkan gigi permanen mengalami erosi sebesar $8,55 \%$. Ganss et.al melaporkan peningkatan persentasi dari erosi gigi pada gigi sulung yaitu sebesar $70,6 \%$, dari gigi permanen dengan persentasi $11.6 \%$. Penelitian Kazoullis et.al menunjukkan erosigigipadagigi sulung sebesar $78 \%$ sedangkan pada gigi permanen sebesar $25 \%$. Besarnya erosi pada gigi sulung terjadi akibat perbedaan morfologis dan lapisan enamel yang lebih tipis dari gigi permanen. Johansson et.al menyatakan bahwa kekerasan mikro pada enamel gigi sulung lebih rendah dibandingkan dengan gigi permanen, dan enamel gigi sulung mengandung lebih banyak air sehingga meningkatkan permeabilitas enamel gigi sulung. ${ }^{2}$ Penelitian Babu et.al menunjukkan gigi sulung yang mengalami erosi paling besar adalah gigi insisivus sentral maksila sebesar $32.81 \%$. Penelitian serupa oleh Wiegand et.al menyebutkan gigi yang mengalami erosi terbesar adalah gigi sulung insisivus maksila yaitu sebanyak $15.5-25 \%$.

Gigi anterior terletak didepan rongga mulut, sehingga lebih terpapar asam ekstrinsik. Dari semua permukaan yang diperiksa, distribusi erosi terlihat lebih predominan pada permukaan labial dari gigi sulung insisivus sentral dan lateral sebesar $32.81 \%$ and $28.39 \%$. Deshpande et.al melaporkan bahwa permukan bukal dan palatal dari inisivus sentral menunjukkan erosi maksimum sebesar 35\% and $21.6 \%{ }^{2}$ Faktor penyebab erosi gigi terbagi menjadi intrinsik dan ekstrinsik. Faktor intrinsik erosi gigi adalah ketika asam lambung mencapai mulut akibat regurgitasi, muntah, atau penyakit gastro-oesophageal reflux. Penyebab ekstrinsik termasuk lingkungan, medikasi, gaya hidup dan diet. Menurut M.L Hunter et.al terdapat hubungan antara kebiasaan diet dengan erosi gigi. Penyebab erosi gigi yang paling sering terjadi adalah akibat makanan dan minuman yang asam. Makanan dan minuman dengan pH dibawah 5,7 diketahui merupakan pemicu erosi gigi. ${ }^{1,3,4}$ Asam pada makanan, seperti asam malat, asam laktat, dan asam fosfat berhubungan dengan perkembangan erosi gigi. Perbedaan potensi erosif asam tersebut berhubungan dengan sifat kimia dan komposisi pada makanan atau minuman asam, termasuk $\mathrm{pH}$, keasaman yang dapat di titrasi kemampuan buffer, jumlah kalsium, fosfat dan fluor. ${ }^{5}$ Perhatian khusus ditujukan kepada asam sitrat, karena banyak terdapat pada buah dan jus buah yang mengandung asam. Jus buah dipandang sebagai sumber nutrisi, sehingga orang tua tidak membatasi konsumsi pada anak. Menurut penelitian Gubat et.al, di Filipina, rata-rata konsumsi minuman tertinggi pada anak usia 6 bulan hingga 5 tahun adalah minuman jus buah dengan jumlah 250 hingga $300 \mathrm{ml} /$ hari. ${ }^{6,7}$ Konsumsi jus buah dalam kemasan memiliki beberapa keuntungan, namun juga memiliki potensi pengaruh buruk bagi kesehatan. Terdapat ketidakpedulian secara luas terhadap erosi gigi sulung yang disebabkan oleh asam, terutama pada kasus erosi gigi akibat jus buah dalam kemasan, karena dianggap sebagai kebiasaan yang sehat. Hal inimenyebabkan penulis tertarik untuk meneliti bagaimana pengaruh minuman jus buah dalam kemasan terhadap erosi gigi sulung anterior rahang atas.

Gigi primer atau gigi sulung berasal dari bahasa latin decider yang berarti tanggal atau lepas. Gigi sulung tanggal atau lepas dan digantikan oleh gigi dewasa. Gigi sulung berfungsi didalam mulut selama 6-10 tahun dalam masa hidup anak. Gigi sulung berjumlah 20 buah pada mulut dengan jumlah lima gigi di setiap kuadran, yaitu gigi insisivus sentral, insisivus lateral, kaninus, molar pertama dan molar kedua, Tidak terdapat gigi premolar sulung. Ketika gigi permanen menggantikan gigi sulung, gigi molar sulung digantikan oleh premolar. Gigi molar permanen tidak memiliki gigi sulung pendahulu dan bererupsi pada sebelah distal gigi sulung. ${ }^{15,16}$

Gigi sulung memiliki ukuran yang lebih kecil dibandingkan gigi permanen dengan nama yang sama, sebagai contoh gigi insisivus dan kaninus sulung lebih kecil dari gigi insisivus dan kaninus permanen. Mahkota dan akar gigi sulung memiliki ciri berupa konstriksi pada servikal, sehingga mahkota gigi sulung terutama pada permukaan fasial dan lingual lebih cembung di dekat garis servikal sehingga membentuk linggir servikal labial dan singulum lingalis yang lebih menonjol dibandingkan gigi permanen. Gigi sulung juga memiliki akar yang lebih panjang dari pada mahkota, warna yang lebih putih dan bentuk yang lebih serupa dibandingkan dengan gigi permanen. ${ }^{15}$ Kehilangan jaringan akibat erosi merupakan bagian dari keausan fisiologis pada gigi. Erosi gigi sebagai suatu kondisi atau bersifat patologis cukup mudah dibedakan pada kasus nyeri atau komplikasi endodontik, namun sulit dibedakan dalam kasus estetik. Dapat disimpulkan bahwa kasus erosi gigi dideskripsikan sebagai sebuah kondisi dan 
asam adalah penyebab non patologis dari erosi gigi. Ketika keadaan asam beraksi cukup lama, defek klinis akan terlihat. ${ }^{10}$

Jus buah dalam kemasan mengandung 10\% sampai $99 \%$ jus buah asli dan ditambahkan pemanis, penambah rasa, vitamin $\mathrm{C}$ atau kalsium. Komponen predominan dalam jus buah dalam kemasan adalah air. Karbohidrat termasuk sukrosa, fruktosa, glukosa dan sorbitol adalah komponen terbanyak setelah air. Konsentrasi fluor pada jus buah dalam kemasan bervariasi, mulai dari 0,02 sampai 2,8 ppm. Komposisi rata-rata asam askorbat dan asam sitrat adalah 500 $\mathrm{mg} / \mathrm{L}$ dan $7500 \mathrm{mg} / \mathrm{L}$ dengan $\mathrm{pH} 3,84.1,8$

Agar sebuah produk dilabelkan sebagai jus buah, US Food and Drug Administration memandatkan produk tersebut harus $100 \%$ jus buah. Untuk jus yang di rekonstitusi dari konsentrat, label produk harus menyatakan bahwa produk tersebut di rekonstitusi dari konsentrat. Minuman yang kurang dari 100\% jus buah harus memasukkan jumlah persentase jus buah dan minuman harus dijelaskan dengan kata deskriptif seperti "minuman" atau "cocktail". Secara umum, jus buah mengandung antara 10\% sampai 99\% jus dan ditambahkan pemanis, perisa dan kadang tambahan penguat seperti vitamin $\mathrm{c}$ atau kalsium. Bahan tambahan ini harus di sertakan pada label menurut US Food and Drug Administration. ${ }^{8}$ Tujuan penelitian ini adalah untuk mengetahui apakah terdapat pengaruh minuman jus buah dalam kemasan terhadap erosi gigi sulung anterior rahang atas.

\section{METODE}

Penelitian ini merupakan penelitian eksperimental labolatorium semu. Penelitian ini menggunakan gigi anterior sulung rahang atas yang dialiri larutan jus buah dalam kemasan. Populasi penelitian adalah gigi sulung dengan mahkota yang masih lengkap, kriteria sampel penelitian adalah kriteria inklusi adalah gigi sulung anterior rahang atas, sedangkan kriteria eksklusi adalah gigi yang mengalami erosi, fraktur dan karies. Alat dan bahan penelitian yang digunakan adalah: Masker, Handscoen, Separating disc, pH meter, Stopwatch, Gelas ukur, Alat pengalir larutan, 2 buah selang infus, Gelas penampung aliran larutan, dan Scanning Electron Microscopy (SEM). Bahan yang digunakan dalam penelitian ini adalah sebagai berikut: 8 buah gigi sulung anterior rahang atas, $250 \mathrm{ml}$ minuman jus buah dalam kemasan, 250 $\mathrm{ml}$ larutan fisiologis, dan $100 \mathrm{ml}$ Aquades sebagai larutan fisiologis. Pemeriksaan mikrostruktur dilakukan pada sampel dengan menggunakan Scanning Electron Microscopy (SEM). Sampel penelitian ini terdapat 2 kelompok dengan 16 sampel perkelompok sehingga didapat jumlah sampel sebesar 32 permukaan. Sampel pada penelitian ini terdapat 2 kelompok: kelompok 1 adalah gigi anterior sulung rahang atas dialiri dengan cairan fisiologis selama 120 menit sebagai kontrol dan kelompok 2 adalah gigi anterior sulung rahang atas yang dialiri larutan jus buah dalam kemasan selama 2 menit secara bergantian dengan pengaliran cairan fisiologis setiap 2 menit, hingga total waktu pengaliran jus buah dalam kemasan selama 120 menit. Masingmasing kelompok dilakukan uji sebelum dan sesudah perlakuan untuk melihat besarnya perbedaan tingkat erosi. Penelitian mengenai pengaruh minuman jus buah dalam kemasan terhadap erosi gigi sulung anterior rahang atas dilakukan pada 2 kelompok spesimen, yaitu kelompok kontrol dan kelompok perlakuan yang terdiri 8 gigi sulung anterior rahang atas. Sebelum dan sesudah perlakuan, spesimen pada kelompok kontrol dan kelompok perlakuan di uji menggunakan Scanning Electron Microscopy (SEM) menggunakan JEOL 6030 LA dengan perbesaran mikro 200x dan 250x untuk melihat karakterisasi morfologi mikrostruktur spesimen berupa perubahan ketebalan enamel akibat erosi oleh minuman jus buah dalam kemasan. Penentuan perbesaran dipengaruhi ketebalan enamel pada spesimen dan tidak mempengaruhi hasil uji SEM. Gambaran erosi gigi didapatkan dengan melakukan preparasi pada gigi sulung anterior rahang atas terlebih dulu secara horizontal hingga 2/3 mahkota, sehingga ketebalan enamel dan dentinoenamel junction (DEJ) pada gigi terlihat dan memungkinkan penghitungan ketebalan enamel gigi dengan karakterisasi SEM. Untuk membantu menentukan lokasi yang sama dan akurat pada analisis SEM setelah perlakuan, dilakukan pencatatan koordinat lokasi pengukuran pada analisis SEM sebelum perlakuan dan sisi kanan dan kiri daerah yang akan dilakukan pengukuran ditandai dengan dioleskan cat kuku. Uji korelasi pada data yang telah terkumpul untuk mengetahui apakah terdapat perbedaan ketebalan enamel gigi sulung anterior rahang atas dengan menggunakan Mann Whitney U Test, yang merupakan uji non parametris yang digunakan untuk mengetahui perbedaan median 2 kelompok bebas apabila skala data variabel terikatnya adalah ordinal atau interval/rasio tetapi tidak berdistribusi normal.

\section{HASIL}

Hasil karakterisasi SEM didapatkan dengan pengambilan gambar spesimen dari aspek penampang dengan perbesaran mikroyang bertujuan mengukur ketebalan enamel pada spesimen. SEM mengukur jarak antara 4 titik terluar permukaan enamel pada aspek labial dengan 4 titik yang berada pada dentinoenamel junction (DEJ) dalam besaran mikrometer $(\mu \mathrm{m})$ untuk menghasilkan 4 ukuran ketebalan yang reratanya melambangkan ketebalan enamel pada spesimen. (B) (C) (D) Gambar 2 Hasil Uji SEM (A) Hasil uji SEM pada spesimen nomor 4 
kelompok kontrol sebelum perlakukan (B) Hasil uji SEM pada spesimen nomor 4 kelompok kontrol setelah perlakuan, (C) Hasil uji SEM pada spesimen nomor 2 kelompok perlakuan sebelum perlakuan
(D) Hasil uji SEM pada spesimen nomor 2 kelompok perlakuan setelah perlakuan.

Tabel 2 Hasil pengukuran erosi enamel gigi dalam besaran

\begin{tabular}{|c|c|c|c|c|c|c|c|}
\hline \multicolumn{4}{|c|}{ Kelompok 1 Kontrol } & \multicolumn{4}{|c|}{$\begin{array}{l}\text { Kelompok } \\
\text { Perlakuan }\end{array}$} \\
\hline Sampel & Sebelum & Sesudah & Beda & Sampel & Sebelum & Sesudah & Beda \\
\hline \multirow{4}{*}{1} & 513.2 & 513.1 & 0.1 & \multirow{4}{*}{1} & 248.9 & 222.1 & 26.8 \\
\hline & 503.6 & 503 & 0.6 & & 249.8 & 217.2 & 32.6 \\
\hline & 502 & 498.8 & 3.2 & & 249.9 & 220.9 & 29 \\
\hline & 494.1 & 494.1 & 0 & & 249.2 & 221.1 & 28.1 \\
\hline Rerata & 503.23 & 502.25 & 0.98 & Rerata & 249.45 & 220.33 & 29.13 \\
\hline \multirow{4}{*}{2} & 325.3 & 321.3 & 4 & \multirow{4}{*}{2} & 188.1 & 158.7 & 29.4 \\
\hline & 324.7 & 322.7 & 2 & & 183.8 & 138 & 45.8 \\
\hline & 311.9 & 311.5 & 0.4 & & 160.2 & 123.6 & 36.6 \\
\hline & 299.6 & 299.3 & 0.3 & & 151.8 & 119.7 & 32.1 \\
\hline Rerata & 315.38 & 313.70 & 1.68 & Rerata & 170.98 & 135.00 & 35.98 \\
\hline \multirow{4}{*}{3} & 245.9 & 244.2 & 1.7 & \multirow{4}{*}{3} & 280.9 & 255.6 & 25.3 \\
\hline & 236.7 & 234.5 & 2.2 & & 267 & 249.4 & 17.6 \\
\hline & 237 & 235.6 & 1.4 & & 263.8 & 256.9 & 6.9 \\
\hline & 217.7 & 213.3 & 4.4 & & 255.4 & 244.7 & 10.7 \\
\hline Rerata & 234.33 & 231.90 & 2.43 & Rerata & 266.78 & 251.65 & 15.13 \\
\hline \multirow{4}{*}{4} & 203.3 & 202 & 1.3 & \multirow{4}{*}{4} & 254.2 & 240.2 & 14 \\
\hline & 195.2 & 194.5 & 0.7 & & 255.7 & 246.7 & 9 \\
\hline & 187.7 & 187.4 & 0.3 & & 259 & 253.6 & 5.4 \\
\hline & 191.4 & 189.3 & 2.1 & & 257.8 & 252.5 & 5.3 \\
\hline Rerata & 194.40 & 193.30 & 1.10 & Rerata & 256.68 & 248.25 & 8.43 \\
\hline Total & 4989.3 & 4964.6 & 24.7 & Total & 3775.5 & 3420.9 & 354.6 \\
\hline Rerata & 311.8 & 310.2 & 1.54 & Rerata & 235.9 & 213.8 & 22.1 \\
\hline \multicolumn{3}{|c|}{ Standar deviasi beda ketebalan enamel } & \pm 1.37 & \multicolumn{3}{|c|}{ Standar deviasi beda ketebalan enamel } & \pm 12.46 \\
\hline
\end{tabular}

Tabel 2 menunjukkan bahwa pada sampel 1 kelompok kontrol, rerata dari beda ketebalan enamel sebelum dan sesudah perlakuan pada 4 titik permukaan adalah 0,98 $\mu \mathrm{m}$. Pada sampel 2 kelompok kontrol rerata beda ketebalan enamel 1,68 $\mu \mathrm{m}$. Pada sampel 3 kelompok kontrol rerata beda ketebalan enamel adalah $2.43 \mu \mathrm{m}$. Pada sampel 4 kelompok kontrol rerata beda ketebalan enamel adalah 1,10 $\mu \mathrm{m}$. Total beda ketebalan enamel pada kelompok kontrol adalah 24,7 $\mu \mathrm{m}$, dengan rerata beda ketebalan 1,54 $\mu \mathrm{m}$ pada tiap spesimen. Pada sampel 1 kelompok perlakuan, rerata dari beda ketebalan enamel sebelum dan sesudah perlakuan pada 4 titik permukaan adalah 29,13 $\mu \mathrm{m}$. Pada sampel 2 kelompok perlakuan, rerata beda ketebalan enamel adalah 35,98 $\mu \mathrm{m}$. Pada sampel 3 kelompok perlakuan, rerata beda ketebalan enamel adalah 15,13 $\mu \mathrm{m}$. Pada sampel 4 kelompok perlakuan, rerata beda ketebalan enamel adalah 8,43 $\mu \mathrm{m}$. Sampel 1 dan 2 dengan rerata 29,13 $\mu$ m dan 35,98 $\mu \mathrm{m}$ pada kelompok perlakuan adalah gigi sulung insisivus sentral rahang atas, tampak memiliki jumlah beda ketebalan enamel yang lebih besar dibandingkan dengan sampel 3 dan 4 dengan rerata 15,13 $\mu \mathrm{m}$ dan 8,43 $\mu$ m yang merupakan gigi sulung kaninus rahang atas.

Total beda ketebalan enamel pada kelompokperlakuan adalah 354,6 $\mu \mathrm{m}$, dengan rerata beda ketebalan 22,1 um pada tiap spesimen. Rerata perbedaan pada 
kelompok kontrol sebesar 1,54 $\mu$ m sedangkan rerata perbedaan pada kelompok perlakuan sebesar 22,1 $\mu \mathrm{m}$ menunjukkan bahwa beda ketebalan enamel pada kelompok perlakuan yang dialiri dengan minuman jus buah dalam kemasan lebih besar dibandingkan dengan kelompok kontrol yang dialirkan dengan cairan fisiologis.

Tabel 3. Hasil pengamatan pada permukaan enamel gigi

\begin{tabular}{cccccc}
\hline & \multicolumn{2}{c}{ Kelompok 1 Kontrol } & \multicolumn{2}{c}{ Kelompok 2 Perlakuan } \\
\hline Sampel & $\begin{array}{c}\text { Struktur } \\
\text { Permukaan }\end{array}$ & Mikroporositas & Sampel & $\begin{array}{c}\text { Struktur } \\
\text { Permukaan }\end{array}$ & Mikroporositas \\
\hline 1 & Sama & Tidak ada & 1 & Berubah & Tidak Ada \\
2 & Sama & Tidak ada & 2 & Berubah & Ada \\
3 & Berubah & Tidak ada & 3 & Berubah & Tidak ada \\
4 & Sama & Tidak ada & 4 & Berubah & Ada \\
\hline
\end{tabular}

Tabel 3 menunjukkan bahwa pada sampel 1, 2 dan 4 kelompok kontrol tidak tampak perubahan mikrostruktur permukaan enamel pada permukaan yang mengalami pengaliran cairan fisiologis, dimana sebelum perlakuan tampak pola guratan akibat separating disc yang digunakan pada saat preparasi, setelah perlakuan pola guratan tetap ada namun beberapa struktur mikro yang terlihat menghilang akibat pengaliran cairan fisiologis. Namun, pada sampel 3 kelompok kontrol tampak perubahan mikrostruktur permukaan enamel tanpa adanya pembentukan mikroporositas. Seluruh spesimen kelompok perlakuan tampak mengalami perubahan mikrostruktur permukaan enamel pada aspek penampang yang mengalami preparasi, dimana sebelum perlakuan tampak pola guratan akibat separating disc yang digunakan pada saat preparasi dan setelah perlakuan pola guratan menghilang digantikan mikrostruktur yang lebih halus. Pada permukaan sampel 2 dan 4 kelompok perlakuan, permukaan penampang tampak mengalami pembentukkan mikroporositas.Hasil uji korelasi dapat dilihat pada tabel berikut:

Tabel 4 hasil uji

\begin{tabular}{cc}
\hline Hasil Uji & Perbedaan \\
\hline Mann-Whitney U & 0.000 \\
Wilcoxon W & 136.000 \\
Z & -4.825 \\
Asymp. Sig. (2-tailed) & 0.000 \\
Exact Sig. [2*(1-tailed Sig.)] & $0.000^{\mathrm{a}}$ \\
\hline
\end{tabular}

Tabel 4 menunjukkan nilai uji Mann-Whitney U sebesar 0,000 dan nilai Wilcoxon W sebesar 136,000. Apabila dikonversikan ke nilai Z maka besarnya
$-4,825$. Nilai p-value adalah $0,000^{\mathrm{a}}<$ batas kritis 0,05 maka dapat disimpulkan bahwa terdapat perbedaan bermakna antara dua kelompok dimana $\mathrm{H}_{1}$ diterima dan $\mathrm{H}_{0}$ ditolak, yang berarti terdapat pengaruh minuman jus buah dalam kemasan terhadap erosi gigi sulung anterior rahang atas.

\section{PEMBAHASAN}

Tabel 2 menunjukkan perbedaan rerata yang cukup besar pada kelompok perlakuan dengan rerata perbedaan pada kelompok kontrol. Menurut hasil statistik menggunakan Mann Whitney U Test pada tabel 4 data penelitian dikatakan signifikan.

Tabel 2 menunjukkan rerata perbedaan ketebalan enamel pada kelompok kontrol tidak dapat dikatakan telah mengalami erosi, sedangkan pada kelompok perlakuan dapat dikatakan telah mengalami erosi yang cukup besar. Hal ini disebabkan ketebalan permukaan yang dapat dikatakan mengalami erosi pada enamel berkisar $2-5 \mu \mathrm{m}$.

Perlakuan pada penelitian ini dilakukan menggunakan jus buah dalam kemasan yang memiliki tingkat keasaman di bawah $\mathrm{pH} 5,7$, yaitu $\mathrm{pH}$ 3,84 Makanan dan minuman dengan $\mathrm{pH}$ dibawah 5,7 diketahui merupakan pemicu erosi gigi. Erosi terjadi apabila enamel gigi berada dalam suatu lingkungan yang asam dengan $\mathrm{pH}$ di bawah 5,5. Minuman yang menyebabkan demineralisasi enamel gigi adalah minuman yang mempunyai $\mathrm{pH}$ rendah dan kapasitas buffer tinggi.., ${ }^{4,23,24,25}$. Reaksi kimia pelepasan ion kalsium dari enamel gigi dalam suasana asam ditunjukkan dengan persamaan reaksi sebagai berikut: $\mathrm{Ca}_{10}\left(\mathrm{PO}_{4}\right)_{6}(\mathrm{OH})_{2}$ menjadi $10 \mathrm{Ca}^{2+}+6 \mathrm{PO}^{3-}+$ $2 \mathrm{OH}$. Reaksi di atas menunjukkan hidroksiapatit dan ion hidrogen akan berubah menjadi ion gas bebas, hydrogen fosfat dan air, dimana ion $\mathrm{OH}$ - akan diubah 
oleh ion $\left[\mathrm{H}^{+}\right]$ke bentuk $\mathrm{H}_{2} \mathrm{O}$ dan $\mathrm{PO}^{3-}$ menjadi bentuk $\mathrm{HPO}^{2-}$ yang jika berkontak dengan asam dalam waktu yang lama akan berubah menjadi $\mathrm{H}_{2} \mathrm{PO}$ - Hal ini akan menyebabkan berkurangnya ion $\left[\mathrm{OH}^{-}\right]$ dan $\left[\mathrm{PO}^{3-}{ }^{3} .25,26\right.$. Perbedaan ketebalan enamel yang berbeda pada kelompok perlakuan dan kelompok kontrol yang terlihat pada tabel 2 menunjukkan tingkat erosi yang lebih tinggi akibat jus buah dalam kemasan dengan $\mathrm{pH}$ 3,84 dibandingkan dengan larutan fisiologis dengan $\mathrm{pH}$ 6,8. Pengaruh $\mathrm{pH}$ terhadap koefisien laju reaksi menunjukkan bahwa semakin kecil atau semakin asam media, maka makin tinggi laju reaksi pelepasan ion kalsium dari enamel gigi. 26,30

Tabel 3 menunjukkan seluruh spesimen kelompok perlakuan mengalami perubahan mikrostruktur enamel yang lebih halus dan pada permukaan sampel 2 dan 4 kelompok perlakuan, permukaan penampang tampak mengalami pembentukkan mikroporositas. Pada erosi gigi tahap lanjut, permukaan enamel gigi akan semakin licin serta permukaan gigi menjadi rata. Demineralisasi yang terjadi secara terus menerus dapat menyebabkan hilangnya kristal hidroksiapatit sehingga struktur permukaan enamel berubah lebih berpori sehingga meningkatkan mikroporositas pada enamel. ${ }^{26,27}$

Tabel 2 menunjukkan bahwa sampel 1 dan 2 kelompok perlakuan yang merupakan gigi sulung insisivus sentral rahang atas, tampak memiliki beda ketebalan enamel yang lebih besar dibandingkan dengan sampel 3 dan 4 kelompok perlakuan yang merupakan gigi sulung kaninus rahang atas. Lama gigi sulung insisivus rahang atas berada dalam rongga mulut dari sejak erupsi hingga tanggal adalah selama 6-7 tahun, lebih singkat daripada gigi sulung kaninus rahang atas yang berada didalam rongga mulut selama 9-10 tahun. Semakin lama gigi berada di dalam rongga mulut, maka semakin banyak proses remineralisasi yang telah dialami, sehingga menyebabkan kandungan mineral pada enamel meningkat. ${ }^{28,29,30}$

Penelitian ini memiliki beberapa kekurangan, yaitu dilakukan tanpa penggunaan agen remineralisasi yang terkandung dalam saliva seperti bikarbonat dan urea serta penyesuaian suhu, sehingga tidak dapat sepenuhnya mewakili keadaan rongga mulut yang sebenarmya. Penggunaan spesimen yang berupa satu jenis gigi dan teknik pemotongan yang disesuaikan mungkin dapat memberikan hasil penelitian yang berbeda. Pemotongan spesimen dilakukan secara manual menggunakan separating disc yang terhubung pada micromotor yang tidak disesuaikan kecepatannya sehingga kemungkinan menyebabkan kerapuhan pada struktur permukaan yang tidak terdeteksi sebelum perlakuan. Analisis lebih lanjut terhadap pembentukan mikroporositas dengan penyesuaian perbesaran uji SEM, serta penghitungan jumlah dan kedalaman mikroporositas yang terbentuk pada permukaan dapat memberikan data penelitian yang lebih luas dalam mempelajari erosi gigi.

Berdasarkan penelitian yang telah dilakukan, disarankan untuk menggunakan sedotan saat mengonsumsi jus buah dalam kemasan untuk mengurangi kontak secara langsung dengan permukaan gigi dan berkumur menggunakan air putih setelah mengonsumsi minuman asam untuk mengurangi demineralisasi. Sebaiknya konsumsi jus buah dalam kemasan dihindari pada anak yang memiliki faktor risiko erosi gigi secara intrinsik.

\section{SIMPULAN}

Terdapat pengaruh minuman jus buah dalam kemasan terhadap erosi gigi sulung anterior rahang atas.

\section{DAFTAR PUSTAKA}

1. Mahamutha A, Gheena. Acid erosion of teeth in a pediatric population. Ponamallae : journal of pharmaceutical dan research; Vol. 7(7), 2015, 435-438.

2. Babu NSV, Kavyashree BS. Prevalence of dental erosion in school going children of south bangalore: a cross-sectional study. Delhi: International Journal of Science Study; 2015; 3(9):74-78.

3. Manaf ZA, Lee MT, Ali NHM, Samynathan S, Jie YP, Ismail NH, Yong BHY. Relationship between food habits and tooth erosion occurrence in malaysian university students. Kuala Lumpur: Universiti Kebangsaan Malaysia; 2011.

4. Huntera M.L, Westb NX, Hughesb JA, Newcombec RG, Addy M. Erosion of deciduous and permanent dental hard tissue in the oral environment. Elsevier; Journal of Dentistry 28 (2000) 257-263.

5. Scaramucci T, Hara AT, Zero DT, Ferreira SS, Aoki IV. Development of an orange juice surrogate for the study of dental erosion. Braz Dent J (2011) 22(6): 473-478.

6. Mesquita-guimarães KSF, Scatena C, Borsatto MC, Rodrigues-Junior AL, Serra MC. Effect of foods and drinks on primary tooth enamel after erosive challenge with hydrochloric acid. Brazil: Original Research Community Dental Health; 2015.Gubat 
et al. Beverage consumption of filipino children and adolescents. Philipina; Philippine Journal of Science; 2015; 144 (1): 31-41.

7. Heyman MB, Abrams SA. Fruit juice in infants, children, and adolescents: current recommendations. Section on Gastroenterology, hepatology, and nutrition, AAP Committee on nutrition: 2017; 139(6)

8. Owens BM, Mallette JD and Phebus JG. Effects of carbonated cola beverages, sports and energy drinks and orange juice on primary and permanent enamel dissolution. Austin J Dent. 2014;1(1): 1004.

9. Whitford G.M. Dental erosion : from diagnosis to therapy. Karger; 2006.

10. Nozari A, Rahmati A, Shamsaei Z, Pour Hashemi A, Layeghnejad MK, Zamaheni S. Destructive effects of citric acid, lactic acid and acetic acid on primary enamel microhardness. J Dent Sch 2015; 33(1): 66-73.

11. Dennison Barbara, Rockwell Helen, Baker Sharon. Excess Fruit Juice Consumption by Preschool-aged Children Is Associated With Short stature and obesity. Iliinois: American Academy of Pediatrics; 1997;99; 1

12. Lussi Adrian. Dental erosion: from diagnosis to therapy. Department of Preventive, Restorative and Pediatric Dentistry, School of Dental Medicine University of Bern Freiburgstrasse 7 CH-3010 Bern Switzerland : 2006.

13. Jarvinen V.K., Rytomaa I.I., Heinonen O.P. Risk factor in dental erosion. Finland: Department of Cariology, University of Helsinki; 1991: J Dent Res 70(6): 942-947.

14. Scheid, Rickne C. Julian B. Woelfel, and Julian B. Woelfel. Woelfel's dental anatomy: its relevance to dentistry. Philadelphia: Lippincott Williams \& Wilkins; 2007:172-184.

15. Duggal Monty, Cameron Angus, Troumba Jack. At a glance: kedokteran gigi anak. Jakarta : Erlangga 2014.

16. Wangidjaja Itjingningsih. Anatomi Gigi. Jakarta, EGC : 2014; 2.

17. Ash Major M. Wheeler's dental anatomy, physiology, and occlusion. Philadelphia. W.B.
Saunders : 1993.

18. Ireland AJ, Guinness NM, Sherriff M. An investigation into the ability of soft drink to adhere to enamel. Caries Res 1995; 29: 470-6.

19. Heinzt SD, Bastos JRM, Tomita N. Fluoride content and $\mathrm{pH}$ of beverages found on the bazilian market. J Dent Res 1996; 75: 192.

20. Fung R, Yaari AM. Fluoride levels in popular brands of soft drink. J Dent Res 1996; 12:1395.

21. Schuurs AFB. Gebitspathologie, Afwijkigen Van De Harge Tendweefsels. Sutatmi Sutyo, Rafiah Abyono. Potologi gigi-geligi, kelainan jaringan keras gigi. Yogyakarta: Gadjah Mada University Press; 1991. p. 75-163.

22. Idrus I. Perubahan struktur email gigi setelah menggunakan bahan pemutih gigi (bleaching) hidrogen peroksida. Makassar: Fakultas Kedokteran Gigi Universitas Hasanuddin; 2016.

23. Riani Dwi Meiyestri, Oenzil Fadil, Kasuma Nila. Pengaruh aplikasi bahan pemutih gigi karbamid peroksida $10 \%$ dan hidrogen peroksida $6 \%$ secara home bleaching terhadap kekeasan permukaan email gigi. Jurnal Kesehatan Andalas. 2015; 4(2) : 347-8.

24. Wulandari Y, Supriyadi, Sulistiyani. Jarak tanduk pulpa terhadap permukaan oklusal gigi molar satu sulung rahang bawah. Fakultas Kedokteran Gigi, Universitas Jember; 2012.

25. Sabel N. Enamel Of Primary Teeth - Morphological And Chemical Aspects. Department of Pediatric Dentistry Institute of Odontology Sahlgrenska Academy at University of Gothenburg; 2012.

26. Erviana O, Fatmasari D, Benyamin B. Perbedaan kelarutan kalsium pada gigi desidui dan gigi permanen dalam perendaman minuman berkarbonasi rasa buah. Fakultas Kedokteran Gigi Unissula Semarang; 2015.

27. Harshanur, I.W. Anatomi Gigi. Penerbit Buku Kedokteran EGC, Jakarta; 2012.

28. Marito, Tresy Charlotte. Pengaruh minuman ringan berkarbonasi terhadap pelepasan ion kalsium gigi desidui. FKG-UGM Yogyakarta; 2013.

29. Amaechi, B. Higham S, Edgar W, Milosevic. Determinant of the Sites of Dental Erosion. Journal of Dental Research; 1999:1821-1828. 
